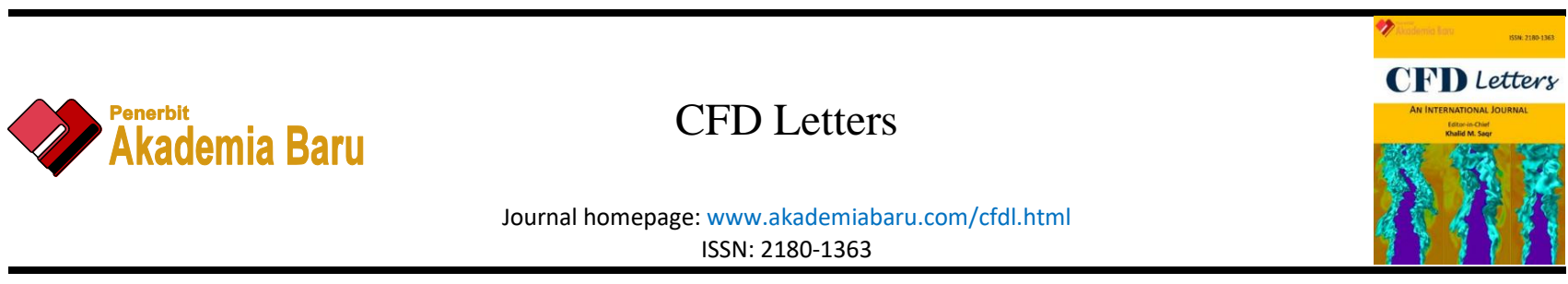

\title{
Coal Type, Temperature and Gasifiying Agent Effects on Low- Rank Coal Gasification Using CFD Method
}

\author{
Kamariah Md Isa ${ }^{1,}$, , Kahar Osman ${ }^{2}$, Nik Rosli Abdullah ${ }^{3}$, Nor Fadzilah Othman ${ }^{4}$, Nurulnatisya \\ Ahmad $^{1}$

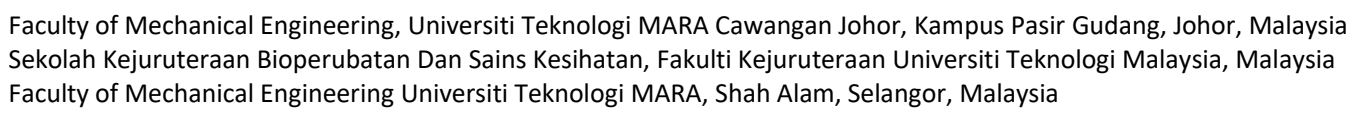

\section{Article history:}

Received 23 August 2020

Received in revised form 22 October 2020

Accepted 25 October 2020

Available online 31 October 2020

\section{Keywords:}

computational fluid dynamics; CFD;

bubbling fluidised bed gasifier; low- rank coal gasification; gasifying agent

\begin{abstract}
Low-Rank Coal (LRC) gasification utilising Fluidised Bed Gasifier (FBG) is more efficient for LRC that has higher reactivity, moisture, tar, volatile, and ash content but lower calorific value compared to other types of coals. This work investigated the application of Computational Fluid Dynamics (CFD) in simulating LRC gasification under different temperatures which is lower (873K), normal (973K) and higher (1073K) temperature atmosphere. Besides that, the effect of LRC type and gasifying agents on the producer gas $\mathrm{CO}+\mathrm{H}_{2}$ composition, Lower Heating Value (LHV) and Cold Gas Efficiency (CGE) were also studied using High-rank Coal (HRC) as comparison. The results obtained showed that LRC gasification using oxygen increased LHV and CGE. Lower temperature gasification using oxygen at 873 increased $\mathrm{CO}+\mathrm{H}_{2}$, LHV and CGE for LRC compared to higher temperatures at $973 \mathrm{~K}$ and $1073 \mathrm{~K}$. This prediction suggests that $\mathrm{LRC}$ gasification using oxygen at lower temperature increases the LRC gasification efficiency.
\end{abstract}

Copyright @ 2020 PENERBIT AKADEMIA BARU - All rights reserved

\section{Introduction}

Coal remains one of the most important sources of energy, fueling almost $40 \%$ of the electricity worldwide and will continue to be an essential global energy source [1-3]. It is forecasted that the importance of coal will continue to grow because of its vast availability and reasonable price [3]. As a clean technology, coal gasification which converts the solid coal into combustible syngas (e.g., $\mathrm{H}_{2}$, $\mathrm{CO}$, and $\mathrm{CH}_{4}$ ) with the resulting high calorific value and low emission was regarded as an efficient route of coal utilization and has attracted increasing attention over the world [4]. Coal gasification can be conducted mainly using either entrained flow gasifier, bubbling fluidized bed gasifier (BFBG), or circulating fluidized bed gasifier (CFBG). The BFBG has been widely adopted due to the advantage

\footnotetext{
* Corresponding author.

E-mail address: kamariahisa@uitm.edu.my (Kamariah Md Isa)
} 
of easy operation, wide solid fuel flexibility, excellent gas-solid mixing, and controllable bed temperature [5]. Plenty of experimental studies towards the coal gasification have been carried out in the past few years [6-10].

Suitable temperature selection can lead to better gasification behavior [11]. Recent technologies for the gasification of coal, in particular, are based on partial combustion at temperatures well above $1000^{\circ} \mathrm{C}$. This high temperature gasification can give a significant advantage in producing very fast thermochemical conversion of coal into syngas but it also provides added expense of chemical energy of the fuel due to heating. Recently, several researchers have shown their interests in lowtemperature gasification with higher cold gas efficiency (CGE) [12-16]. The use of reactive coals and higher volatile content can promote higher carbon conversion during the gasification process [17, 18]. The syngas' calorific value increases when there is a temperature increase. This is contributed by the increased of $\mathrm{CO}$ and $\mathrm{H}_{2}$ concentration in the process [19-21]. The syngas LHV, however, decreases with the increasing temperature. On the other hand, gasification of LRC using lower temperature increases $\mathrm{CO}_{2}$ concentration because of the water-gas shift reactions and oxidation reactions which are very exothermic [19]. LRC is also reported to have a better gasification reactivity and not too dependable to gasification temperature [22]. Thus, it is important to investigate the coal gasification outcome when conducted in various temperature condition.

The composition of the volatiles obtained during gasifications was conducted depends on the degree of the equilibrium of various gasification reactions. Experimental research had been used widely and gave useful insights to understand the gasification process by considering the chemical equilibrium of the gas components. However, it is still very difficult to predict the exact composition of the syngas when conducting the gasification process. The operation of fluidized bed gasifiers is very complex to be determined experimentally because it requires a long duration to explore. This would result in a high operating cost [23]. The steady-state condition in the fluidized bed gasifiers is hard to maintain and changes with the changing of operating parameters [23]. Besides that, the equations used in fluidization problems are non-linear and it is difficult to obtain the exact solution to accurately predict its numerical solutions. With recent developments in technology and numerical techniques together with the reduced cost of CFD software packages, the capability of CFD modelling can overcome the issues that occur during the experimental process.

In recent years, the use of Computational Fluid Dynamics (CFD) simulations had increased with a distinct improvement in calculation methods and the condition of computer hardware. Using CFD is very convenient, low cost and has accurate reproducibility [24]. For the gasification CFD model, it is usually built using the dimension or geometry of a lab-scale, pilot-scale or commercially available gasifier $[25,26]$. Compared to the experiment method, using CFD methods makes it much easier to change the input parameters like the feedstock properties, critical operating parameters such as temperature or pressure, gasifying agents and other parameters that influence the system performances. A comprehensive and validated CFD model using a readily available gasifier is valuable in predicting the gasification efficiency indicator such as syngas production and CGE and whether it is optimised according to its critical parameters [27, 28]. Moreover, CFD simulation is effective when trying to predict flow, temperature, and species distributions during the gasification process which is hard to determine or visualize using the experimental method used previously [28].

Considering the importance and complexity of coal gasification under various parameters such as gasifying agent and operating temperature, the establishment of a fast, simple, accurate, and suitable CFD model has important theoretical and practical engineering value, and it is also useful for the study of the reaction process and reactor design. In this work, a CFD two- dimensional transient simulation of a pilot-scale gasifier were carried out using ANSYS-Fluent. Two- dimensional approach was selected instead of one-dimensional approach due to the variation of an important property of 
the system in a second dimension can no longer be neglected such as the variations of temperature and composition in the axial and radial directions in the gasifier [29]. Even though the threedimensional simulation results will provide good predictions, it requires too much computation time. If a two- dimensional model used can provide key results representing the actual process as well as the three- dimensional model, the simulation efficiency would improve and variable parameter analysis could be performed quickly [30]. The CFD results were compared to experimental results obtained from an actual pilot-scale gasifier. This will serve to check if the model is suitable to accurately simulate the LRC gasification process.

\section{Methodology}

\subsection{Experimental Method}

In this study, all the coal samples were from Tenaga Nasional Berhad Research (TNBR) and also some were obtained by the companies in Sarawak, Malaysia. There are two ranks of coals used, LRCS that consist of sub-bituminous coals and HRC which is bituminous coal. Table 1 shows the origin, type, rank, and reactivity for 5 different coals. The reactivity on the table is calculated by the ratio of fixed carbon/volatile matter [31].

Table 1

LRC and HRC used in this study

\begin{tabular}{llll}
\hline Coal Name & Origin & Type & Rank \\
\hline Merit-Pila & Sarawak, Malaysia & Sub- bituminous & LRC \\
Mukah Balingian & Sarawak, Malaysia & Sub- bituminous & LRC \\
Adaro & Indonesia & Sub- bituminous & LRC \\
Melawan & Indonesia & Sub- bituminous & LRC \\
Silantek & Sarawak, Malaysia & Bituminous & HRC \\
\hline
\end{tabular}

The coal samples preparation was conducted according to the American Society for Testing of Material, ASTM D2013-86. The heating value of every coal used was determined using a bomb calorimeter, LECO AC-350. ASTM D3286-96: Standard test method for gross calorific value of coal and coke using isoperibol bomb calorimeter was used to obtain the calorific value of the coals [32]. ASTM D 5373-93: Standard test methods for instrumental determination of carbon, hydrogen, and nitrogen in laboratory samples of coal and coke was used to investigate the Ultimate Analysis of coal which consists of carbon $(C)$, hydrogen $(H)$, sulphur $(S)$, nitrogen $(N)$ and oxygen $(O)$. ASTM D5142-90: Standard test methods for proximate analysis of the analysis sample of coal and coke by instrumental procedures were used to define the coal characterization in the term of weight loss percentage of moisture, volatile matter, fixed carbon and ash [33]. The experiments were conducted using Thermogravimetric Analyser, TGA/DTA 220U, SEIKO.

A readily-available gasifier at the Combustion Research Group in TNB Research Sdn Bhd was used to conduct the LRC gasification. There are seven main components in this experimental arrangement, which are a steam generator, air/steam blower and distributer, coal feeding, fluidised bed gasifier, pre-heating section and producer gas analysis section which was controlled by the Controller Unit. In this experiment, thermocouples were used inside the gasifier to measure the temperature.

Before the experiment started, around $15 \mathrm{~kg}$ of silica sand was inserted in the gasifier. An electric heater was used to pre-heat the gasifying agent $\left(\sim 150^{\circ} \mathrm{C}\right)$ before entering the gasifier. To develop silica sand's fluidisation, the gasifying agent was continuously supplied. The flow rate of the gasifying agent was controlled using an airflow meter while liquified pressurized gas (LPG) was used to increase the temperature of the bed to a maximum of $400^{\circ} \mathrm{C}$. Coals were continuously supplied to increase 
bed temperature [34-36]. A screw-feeder controller was used to measure and control the coal feed rate. The temperature of the silica bed was maintained to be isothermal at $600-800^{\circ} \mathrm{C}$. The Equivalence Ratio (ER) of 0.3 was used for all experiments to ascertain that the fluidising and gasification process was stable inside the reactor bed. The value of 0.3 was selected as it is widely accepted that the optimum ER is between 0.2 and 0.4 (air supply is only $20-40 \%$ of its stoichiometric requirement) [37]. The entrained particles inside the syngas from the gasifier was captured using two cyclones. Catalysts were used to reduce the tar content in the syngas.

Samples of the product gases were taken from 3 different locations inside the gasifier's freeboard which is at the gasifier, cyclone exit and after the water scrubber. Samples were taken from the produced gas released using online gas chromatography (GC). The GC was equipped with Porapak $Q$ column and Molecular Sieve $5 \mathrm{~A}$ column. The produced gas detection used helium gas as the carrier gas. The analysis of the hydrocarbons and permanent gas analysis was conducted using two detectors which are the flame ionization detector (FID) and the thermal conductivity detector (TCD). The results used in this experiment were all obtained from the gasifier freeboard [34-36].

\subsection{CFD Simulation Method}

The mathematical model was described in detail in a recent publication, thus omitted in this paper [38]. The Eulerian- Eulerian multiphase flow with KTGF was chosen for this study [38-40]. The Eulerian-Eulerian approach was chosen because it is more suitable to be used for the bubbling fluidised bed (BFB) gasifier type. The BFB gasifier has a dense bed making it hard to track the bed or coals particles. Tracking it becomes nearly impossible or very time-consuming. That is why the EulerEuler approach was chosen. The kinetic theory of granular flow (KTGF) was used as the base for the sophisticated closure models. The gasifier geometry, mesh and mathematical model were developed using ANSYS FLUENT version 14 (Ansys, Inc., Cecil Township, PA, USA). UDF or user-defined function was used to model the chemical reactions for heterogeneous reactions. Two Eulerian phases were defined which is the solid phase for coal and silica-sand and the gas phase for the gasifying agent.

The 2 nd order implicit was used for the transient formulation while the Eulerian was used for the multiphase model. The model also applied Realizable k-epsilon dispersed multiphase model and standard wall functions with considerations on the gravitational force. This research used the value recommended for monodispersed particles which are 0.63 for the volume fraction of sand inside the gasifier [41]. The Finite-Rate/Eddy-Dissipation Model was selected to solve the gas-phase species transport equations. This model used Discrete Ordinate (DO) radiation model for the gas and particle radiation interactions. The domain-based weighted-sum-of-gray-gases model (WSGGM) for the radiative properties of the gases was applied [42]. To prevent divergence, under relaxation factor for pressure, momentum and volume fraction were set at 0.1. Second-Order Upwind scheme was selected as the discretization scheme for momentum, turbulence dissipation rate and turbulence kinetic energy. QUICK discretisation scheme is used for time discretization for volume fraction calculation. Phase Coupled SIMPLE was used for pressure-velocity coupling scheme [43]. The models and parameters used in ANSYS FLUENT were as shown in Table 2. 


\section{Table 2}

Simulation and model parameters

\begin{tabular}{lll}
\hline Description & Value & Comments \\
\hline Gasifier height, $\mathrm{H}$ & $3.13 \mathrm{~m}$ & Fixed value \\
Gasifier width & $0.35 \mathrm{~m}$ & Fixed value \\
Static bed height, $\mathrm{H}_{0}$ & $0.525 \mathrm{~m}$ & Fixed value \\
Gas density, $\rho_{\mathrm{g}}$ & $1.225\left(\mathrm{~kg} / \mathrm{m}^{3}\right)$ & Air \\
Gas viscosity, $\mu_{\mathrm{g}}$ & $1.7894 \times 10^{-5}(\mathrm{~kg} / \mathrm{m} \mathrm{s})$ & Air \\
Particle density, $\rho_{\mathrm{s}}$ & $2665\left(\mathrm{~kg} / \mathrm{m}^{3}\right)$ & Silica-sand \\
Particle viscosity, $\mu_{\mathrm{s}}$ & $1.72 \times 10^{-5}(\mathrm{~kg} / \mathrm{m} \mathrm{s})$ & Silica-sand \\
Particle diameter, $\mathrm{d}_{\mathrm{s}}$ & $350 \mu \mathrm{m}$ & Silica-sand, uniform distribution \\
Initial solid volume fraction, & 0.63 & Fixed value \\
E0 & $30^{\circ}$ & \\
Angle of internal friction & 0.7 & Fixed value \\
Restitution coefficient & 0.0001 & Fixed value \\
Specularity coefficient & 0.64 & Fixed value \\
Maximum particle packing & & Fixed value \\
limit & 0.0001 & \\
Time step & $4 U_{\mathrm{mf}}$ & Specified \\
Fluidisation Velocity (m/s) & $873,973,1073$ & \\
Temperature (K) & & Lower, normal and higher operating \\
Coal particle size ( $\mu$ m) & 350 & temperature \\
LRC Type & Merit-Pila, Mukah-Balingian, & Specified \\
HRC Type & Melawan, Adaro & \\
Transient simulation time $(\mathrm{s})$ & 4.0 & \\
Initial pressure (Pa) & 101325 & Specified \\
\hline
\end{tabular}

ANSYS Design-modeler was used to build a two dimensional (2D) axisymmetric geometry gasifier. The gasifier was based on the physical dimensions of the real pilot-scale fluidised bed gasifier at TNBR. First, ANSYS Mesh was used to discretize the gasifier geometry. Then, using a mapped face meshing option and quadrilateral mesh method, the whole gasifier domain was meshed into a large number of elements of quadrilateral shapes as shown in Figure 1. There was no further refinement for the cells made near the wall because this model aimed to capture the gasification processes within the bed and not the near-wall behaviour [44]. Different mesh sizes which are the coarse, medium and fine with three different maximum face sizes of $0.5 \mathrm{~cm}, 0.35 \mathrm{~cm}$ and $0.25 \mathrm{~cm}$ were used in this study. All the mesh types were a near $100 \%$ orthogonal quality with maximum skewness of < $5 \%$. According to the ANSYS manual [45], the mesh quality value was excellent based on the orthogonal quality and skewness value.

The gasification of LRC is a complex process. LRC consists of a different number of substances and it may be different in terms of composition between coals according to their rank, calorific value, ash content, moisture content, etc. Some simplification needs to be applied to the modelling strategy to overcome this complexity issues when developing the CFD model. During LRC gasification, four stages of conversion which are drying, pyrolysis, devolatilisation and char gasification occurs. First, all the volatiles were released and when completed, volatiles oxidation, char combustion and gasification occurred. The chemical reactions that happen during gasification are volatile oxidation (combustion), char combustion (oxidation), char-steam gasification, char-carbon dioxide gasification, followed by the gas phase reactions [46]. Table 3 shows the reactions for the simulation of LRC gasification used in this study. 


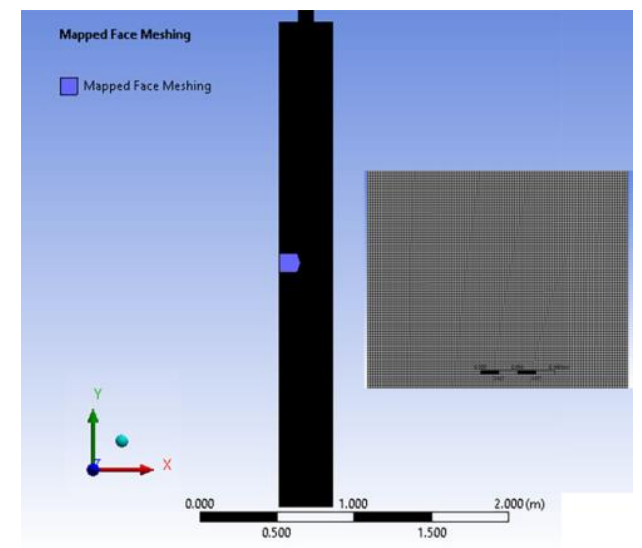

Fig. 1. Geometry and mesh of gasifier generated in ANSYS

\section{Table 3}

Global reaction rates used for coal gasification simulation and model parameters

\begin{tabular}{|c|c|c|c|c|c|}
\hline & \multirow[t]{2}{*}{ Reactions } & \multirow{2}{*}{$\begin{array}{l}\text { Reaction Heat, } \\
\Delta H_{R}^{\circ}(\mathrm{MJ} / \mathrm{kmol})\end{array}$} & \multicolumn{2}{|c|}{$\mathrm{K}=\mathrm{A} \mathrm{t}^{\mathrm{n}} \exp (-\mathrm{E} / \mathrm{RT})(\mathrm{n}=0)$} & \multirow[t]{2}{*}{ Reference } \\
\hline & & & A & $\mathrm{E}(\mathrm{kJ} / \mathrm{mol})$ & \\
\hline \multicolumn{6}{|c|}{ Heterogenous Reactions } \\
\hline LRC 1 & $\mathrm{H}_{2} \mathrm{O}(\mathrm{I}) \rightarrow \mathrm{H}_{2} \mathrm{O}(\mathrm{g})$ & - & 0.05 & 1.08 & Khan and Wang [47] \\
\hline LRC 2 & $\begin{array}{l}\text { Volatile } \rightarrow \mathrm{v}_{1} \mathrm{CH}_{4}+\mathrm{v}_{2} \mathrm{H}_{2}+\mathrm{v}_{3} \mathrm{CO}_{2} \\
+\mathrm{v}_{4} \mathrm{CO}+\mathrm{v}_{5} \mathrm{H}_{2} \mathrm{O}+\mathrm{v}_{6} \operatorname{tar}\end{array}$ & \multicolumn{3}{|c|}{ User Defined Function (UDF) } & \\
\hline LRC 3 & $\mathrm{C}(\mathrm{s})+0.5 \mathrm{O}_{2} \rightarrow \mathrm{CO}$ & \multicolumn{3}{|c|}{ User Defined Function (UDF) } & \\
\hline LRC 4 & $\mathrm{C}(\mathrm{s})+\mathrm{CO}_{2} \rightarrow 2 \mathrm{CO}$ & \multirow{2}{*}{\multicolumn{3}{|c|}{$\begin{array}{l}\text { User Defined Function (UDF) } \\
\text { User Defined Function (UDF) }\end{array}$}} & \\
\hline LRC 5 & $\mathrm{C}(\mathrm{s})+\mathrm{H}_{2} \mathrm{O} \rightarrow \mathrm{CO}+\mathrm{H}_{2}$ & & & & \\
\hline \multicolumn{6}{|c|}{ Homogenous Reactions } \\
\hline LRC 6 & $\mathrm{CO}+0.5 \mathrm{O}_{2} \rightarrow \mathrm{CO}_{2}$ & -283.0 & $2.2 \times 10^{12}$ & $1.67 \times 10^{8}$ & Lu and Wang [48] \\
\hline LRC 7 & $\mathrm{CO}+\mathrm{H}_{2} \mathrm{O} \rightarrow \mathrm{CO}_{2}+\mathrm{H}_{2}$ & - & $2.75 \times 10^{10}$ & $8.38 \times 10^{7}$ & Lu and Wang [48] \\
\hline LRC 8 & $\mathrm{CO}+3 \mathrm{H}_{2} \rightarrow \mathrm{CH}_{4}+\mathrm{H}_{2} \mathrm{O}$ & - & $4.4 \times 10^{11}$ & $1.25 \times 10^{8}$ & Jeong et al., [49] \\
\hline LRC 9 & $\mathrm{CH}_{4}+0.5 \mathrm{O}_{2} \rightarrow \mathrm{CO}+2 \mathrm{H}_{2}$ & -35.71 & $4.4 \times 10^{11}$ & $1.25 \times 10^{8}$ & $\begin{array}{l}\text { Jeong et al., [28], } \\
\text { Jones and Lindstedt } \\
{[50]}\end{array}$ \\
\hline LRC 10 & $\mathrm{H}_{2}+0.5 \mathrm{O}_{2} \rightarrow \mathrm{H}_{2} \mathrm{O}$ & -242 & $5 \times 10^{10}$ & $1.68 \times 10^{8}$ & Chen et al., [51] \\
\hline
\end{tabular}

The simulation iterations were conducted using a time step size of $0.001 \mathrm{~s}$ until $0.0001 \mathrm{~s}$. The simulation was stopped at 4:00s because the syngas production reaches a steady state at that time and the value remains almost constant [47]. It was assumed that the mixture inside the gasifier was an ideal gas mixture as the gasifier and was at atmospheric pressure. Because the bed was a homogeneous porous media, all the variables were also assumed as continuous in space and time. Other than that, the wall was considered adiabatic, with heat $u_{x}=0$. The coal pyrolysis process was considered to happen instantaneously, which made the process simpler. The coal properties obtained from the experimental results were used as an input in coal inlet and the char composed of pure carbon.

The numerical method and grid convergence study in this paper is not included as it was reported before in our recent paper [38].

\subsection{Performance Evaluation of Gasification Process}

Several ways can be used to evaluate the performance of the gasification process. The gasification performance was assessed using the same method applied by Ghezelchi [52] and others [53-55]. 
Besides syngas components $\left(\mathrm{CO}+\mathrm{H}_{2}\right)$, lower heating value (LHV) and cold gas efficiency (CGE), $\eta$ were also calculated. The equations that were used are as shown in Eq. (1) and Eq. (2) below.

$\mathrm{LHV}_{\text {syngas }}=\left(\left(30 \mathrm{CO}+25.7 \mathrm{H}_{2}+85.4 \mathrm{CH}_{4}\right) \times 4.2\right) \times 1000\left(\mathrm{MJ} / \mathrm{Nm}^{3}\right)$

$\mathrm{CO}, \mathrm{H}_{2}$ and $\mathrm{CH}_{4}$ are the molar ratios of each species as obtained from gasifier simulation results.

$\eta=\frac{m_{\text {syngas }} \cdot L H V_{\text {syngas }}}{m_{\text {fuel }} \cdot L H V_{\text {fuel }}} \times 100$

Where $m_{\text {syngas }}$ and $m_{\text {fuel }}$ is the mass flow rate for syngas and fuel $[16,56]$.

\section{Results}

\subsection{Investigation of Coal Properties}

Table 4 and Table 5 list the calorific value, proximate and ultimate analysis results conducted. The values were used in the FLUENT simulation as the volatile composition of coal.

\section{Table 4}

Proximate and ultimate analysis for LRC used

\begin{tabular}{lllll}
\hline Parameters & Melawan & Adaro & Merit-Pila & Mukah Balingian \\
\hline Calorific Value J/g & 21878 & 28340 & 24490 & 24565 \\
$\begin{array}{l}\text { PROXIMATE ANALYS (as received) } \\
\text { Moisture }\end{array}$ & 24.5 & 8.38 & & \\
Volatile Matter & 32.49 & 39.27 & 6.11 & 10.27 \\
Fixed Carbon & 39.10 & 43.20 & 37.04 & 35.0 \\
Ash & 4.0 & 9.15 & 39.11 & 43.36 \\
ULTIMATE ANALYSIS (d.a.f) \% & & 17.75 & 11.38 \\
Carbon & 74.1 & 43.97 & & \\
Hydrogen & 5.3 & 4.33 & 58.49 & 64.54 \\
Nitrogen & 1.48 & 1.03 & 4.94 & 4.83 \\
Oxygen & 18.85 & 50.67 & 0.53 & 1.09 \\
Sulfur & 0.27 & 0 & 36.05 & 29.58 \\
\hline
\end{tabular}

Table 5

Proximate and ultimate analysis for HRC used

\begin{tabular}{lc}
\hline Parameters & Silantek \\
\hline Calorific Value J/g & 28700 \\
PROXIMATE ANALYSIS (as received) \% & 29.09 \\
Moisture & 31.22 \\
Volatile Matter & 31.18 \\
Fixed Carbon & 8.51 \\
Ash & \\
ULTIMATE ANALYSIS (d.a.f) \% & \\
Carbon & 78.40 \\
Hydrogen & 5.4 \\
Nitrogen & 2.3 \\
Oxygen & 0.4 \\
Sulfur & 0.4 \\
\hline
\end{tabular}




\subsection{Validation of the Gasification Model}

A validated gasification model can be used to assessed the gasifier's performance sensitivity when using different operating parameters [24]. The impact of the parameters to the gasification efficiency can be predicted using the gasification model developed without further need of the experimental data [24]. The species composition of syngas produced from gasification of Merit- Pila, Melawan and Adaro coal from experiment and the prediction made by CFD simulation were summarised in Table 6 below.

Table 6

Comparison of Syngas Composition between Simulation and Experiment

\begin{tabular}{lllll}
\hline Adaro & & & & \\
\hline Syngas Species & $\begin{array}{l}\text { Experiment } \\
(\text { mol.\%) }\end{array}$ & $\begin{array}{l}\text { Simulation } \\
(\text { mol.\%) }\end{array}$ & $\begin{array}{l}\text { Absolute Error } \\
(\%)\end{array}$ & $\begin{array}{l}\text { Relative Error } \\
(\%)\end{array}$ \\
$\mathrm{CH}_{4}$ & 0.110 & 0.220 & 0.110 & 100 \\
$\mathrm{O}_{2}$ & 11.795 & 2.228 & 9.566 & 81.102 \\
$\mathrm{CO}_{2}$ & 8.573 & 5.072 & 3.502 & 40.849 \\
$\mathrm{CO}+\mathrm{H}_{2}$ & 15.256 & 17.495 & 2.239 & 14.677 \\
$\mathrm{~N}_{2}$ & 64.266 & 74.985 & 10.719 & 16.679 \\
\hline Merit-Pila & & & & \\
\hline Syngas Species & Experiment & Simulation & Absolute Error & Relative Error \\
& $($ mol.\%) & $($ mol.\%) & $(\%)$ & $(\%)$ \\
$\mathrm{CH}_{4}$ & 1.061 & 0.914 & 0.147 & 13.855 \\
$\mathrm{O}_{2}$ & 0.951 & 1.661 & 0.710 & 74.659 \\
$\mathrm{CO}$ & 8.922 & 5.217 & 3.705 & 41.527 \\
$\mathrm{CO}+\mathrm{H}_{2}$ & 15.681 & 16.289 & 0.608 & 3.877 \\
$\mathrm{~N}_{2}$ & 73.167 & 75.918 & 2.751 & 3.760 \\
\hline $\mathrm{Melawan}_{\mathrm{Syngas} \mathrm{Species}}$ & Experiment & Simulation & Absolute Error & Relative Error \\
& $($ mol.\%) & $($ mol.\%) & $(\%)$ & $(\%)$ \\
$\mathrm{CH}_{4}$ & 0.140 & 0.291 & 0.150 & 107.14 \\
$\mathrm{O}_{2}$ & 11.892 & 1.587 & 10.304 & 86.646 \\
$\mathrm{CO}_{2}$ & 2.362 & 2.678 & 0.316 & 13.378 \\
$\mathrm{CO}+\mathrm{H}_{2}$ & 15.846 & 14.926 & 0.919 & 5.800 \\
$\mathrm{~N}_{2}$ & 69.760 & 80.518 & 10.758 & 15.421 \\
\hline
\end{tabular}

Table 6 shows a comparison of syngas species mol fractions between CFD simulation and experiment. From the observation on the data in Table 6, the CFD simulation results have good agreement with experimental data for all species composition with an absolute error below $11 \%$ for Adaro and Melawan coal and below 4\% for Merit-Pila coal. For relative errors, it can be seen that the value is significantly high for $\mathrm{CH}_{4}$ and $\mathrm{O}_{2}$. The range of relative errors obtained is similar to the report by Battaglia et al., [57] which conducted a comparison between experimental and CFD simulation for low-rank sub-bituminous coals. The difference in the results might be caused by the reaction kinetics used in the simulation is not suitable for LRC because most of the reaction kinetics obtained from literature was for HRC gasification instead of LRC [58]. Further improvement can be made to the $\mathrm{O}_{2}$ and $\mathrm{CH}_{4}$ composition results using CFD simulation by conducting a kinetic study specifically for the sample used instead of using the reaction kinetics available in the literature [59].

Besides that, the high alkaline content in low-rank coals might also be a contributor to the difference in experiment and CFD results. Low-rank coal reactivities were reported to be associated with the alkaline content $[60,61]$. It is also reported that the activation energy might differ even though the coals are from the same rank [61-63]. However, this simulation does not consider this 
effect even though its catalytic nature has been widely mentioned as a variable affecting the activation energy of coals $[61,64,65]$. Addition of the alkaline content in coals and its effect on coal gasification in the simulation model is thought to provide a more accurate result for the CFD simulation. Other than that, the assumptions or simplifications made during the simulation were also known to produce some errors. The results for $\mathrm{C}_{2} \mathrm{H}_{6}, \mathrm{C}_{2} \mathrm{H}_{4}$ and $\mathrm{C}_{2} \mathrm{H}_{2}$ were neglected as the amount is too small compared to other producer gas composition.

$\mathrm{CO}+\mathrm{H}_{2}$ which was the desired syngas components was selected as the gasifier performance evaluator because its total mols did not change by the water-shift reaction. Besides that, the gasification reactivity is correlated to its syngas yield and the total percentage of $\mathrm{CO}$ and $\mathrm{H}_{2}$ in the syngas, not to the $\mathrm{H}_{2} / \mathrm{CO}$ ratio. Due to the convenience, $\mathrm{CO}+\mathrm{H}_{2}$ was used in this study [66].

\subsection{Comparison between LRC and HRC Gasification using Air as Gasifying Agent}

The simulation results of the desired syngas components $\left(\mathrm{CO}+\mathrm{H}_{2}\right)$, Lower Heating Value (LHV) and Cold Gas Efficiency (CGE) inside a gasifier for five types of different coals using CFD simulation is as shown in Table 7 below. The coals used in this study is Merit-Pila, Mukah Balingian, Melawan, and Adaro for LRC and Silantek for HRC. To compare the gasification of coals between LRC and HRC, the simulation was first conducted using air gasification at $973 \mathrm{~K}$.

Table 7

Comparison of $\mathrm{CO}+\mathrm{H}_{2}$ composition, LHV and CGE between HRC and LRC at 973K using CFD simulation

\begin{tabular}{lllll}
\hline Coal type & Coal & $\begin{array}{l}\text { Syngas }\left(\mathrm{CO}+\mathrm{H}_{2}\right) \\
(\text { mol fraction }(\%))\end{array}$ & LHV $\left(\mathrm{MJ} / \mathrm{Nm}^{3}\right)$ & CGE (\%) \\
\hline LRC & Merit-Pila & 15.59 & 2.27 & 7.48 \\
LRC & Mukah- balingian & 18.78 & 2.65 & 8.70 \\
LRC & Adaro & 17.39 & 2.26 & 6.43 \\
LRC & Melawan & 14.63 & 1.94 & 7.15 \\
HRC & Silantek & 23.88 & 4.82 & 13.55 \\
\hline
\end{tabular}

As expected, the results show that the amount of desired syngas components $\left(\mathrm{CO}+\mathrm{H}_{2}\right)$ for $\mathrm{LRC}$ is much lower compared to HRC which is $14.63 \%$ to $18.78 \%$ compared to $23.88 \%$. The LHV result for LRCs (ranged between $1.94 \mathrm{MJ} / \mathrm{Nm}^{3}$ to $2.65 \mathrm{MJ} / \mathrm{Nm}^{3}$ ) were also low compared to HRC (4.82 $\mathrm{MJ} / \mathrm{Nm}^{3}$ ). As indicated by Zaccariello and Mastellone [67], this result might be contributed by the high oxygen and water contents in the LRC (Refer Table 4) that lowers the chemical energy content during gasification. Silantek coal, however, shows the highest amount of LHV even though it contains a high moisture content which is $29.09 \%$. The high LHV value of Silantek might be contributed by the low oxygen content (13.5\%) compared to other LRC. It was influenced by other factors such as coal calorific values and carbon content. The results which show that differences in the coal's composition may present significant variations in the gasification products [67].

From Table 7, the CGE values range from $6.43 \%$ to $8.70 \%$ for LRC coals tested. On the other hand, the CGE value for HRC is $13.55 \%$, which is higher compared to LRCs. Results in Table 7 indicated that gasifying HRC is more efficient than LRC at typical operating temperature ( $973 \mathrm{~K}$ ) based on the CGE values. This result agrees with the results reported by Majoumerd et al., [68]. They reported that the coal quality did influence CGE because they found that gasification of lignite coals (LRC) using the GE gasifier is $29 \%$ lower than gasification using bituminous coal [68]. 


\subsection{Effects of Temperature to LRC Gasification}

Figure 2 shows syngas composition $\left(\mathrm{CO}+\mathrm{H}_{2}\right)$, LHV and CGE for all types of coal during air gasification. The values of syngas produced during gasification reduce for all LRC when the temperature was increased to $1073 \mathrm{~K}$. However, gasification of $\mathrm{HRC}$ at $1073 \mathrm{~K}$ increased syngas composition $\left(\mathrm{CO}+\mathrm{H}_{2}\right)$ by $5.35 \%$. The LHV and CGE results obtained had a similar pattern to the syngas composition (Figures 3 and 4). This suggests that the reactions involved during HRC and LRC gasification differ where LRC favours gasification at $973 \mathrm{~K}$ compared to $1073 \mathrm{~K}$. When gasification is conducted at a lower temperature which is $873 \mathrm{~K}$, only Merit-Pila coal shows an increase in syngas composition. Even though several researchers $[57,69]$ indicates that increasing temperature will increase syngas composition, LHV or CGE, but not all types of coal will have this characteristic. LRC such as Merit-Pila favours lower temperature at $873 \mathrm{~K}$ while other LRC such as Mukah- balingian, Melawan and Adaro favours lower temperature at $973 \mathrm{~K}$ instead of $1073 \mathrm{~K}$.

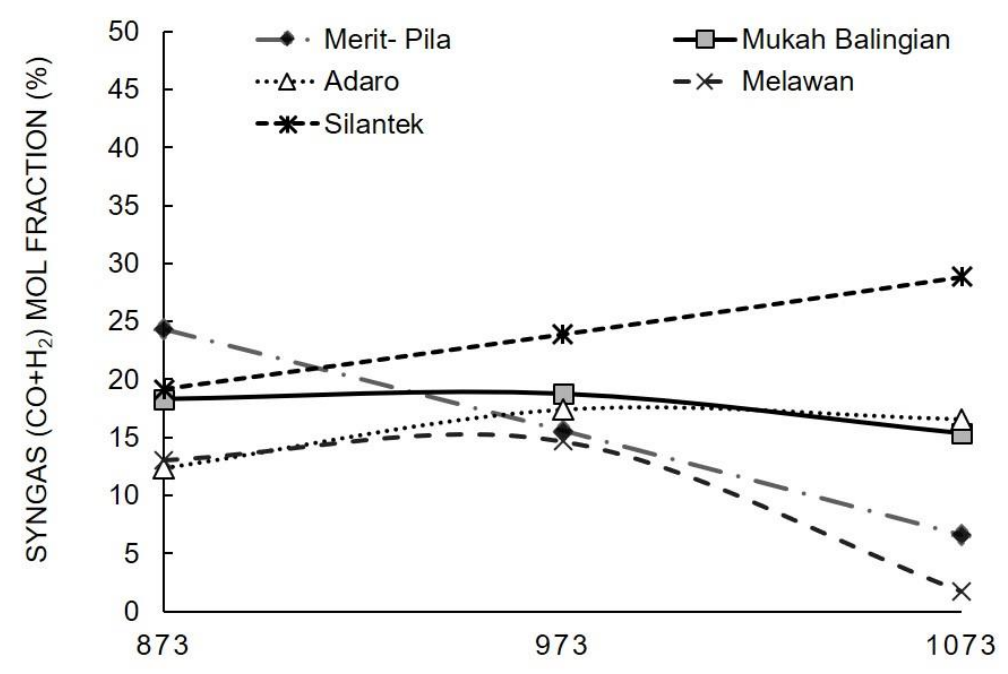

Fig. 2. $\mathrm{CO}+\mathrm{H}_{2}$ of various coals at $873 \mathrm{~K}, 973 \mathrm{~K}$ and $1073 \mathrm{~K}$ using air as gasifying agent (data from CFD simulation result)

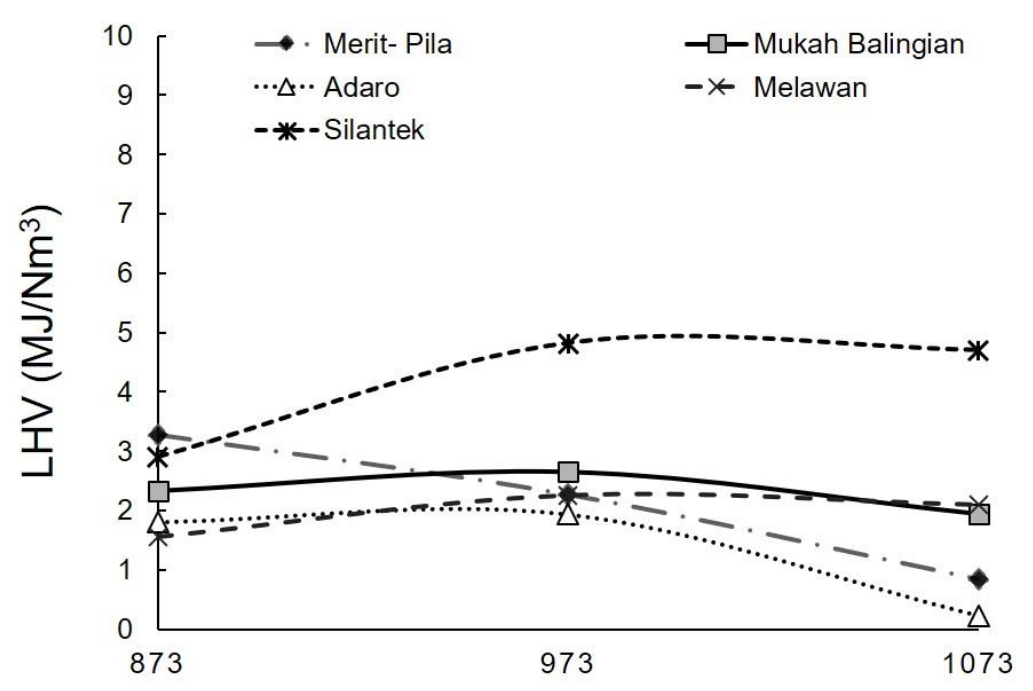

Fig. 3. LHV of various coals at $873 \mathrm{~K}, 973 \mathrm{~K}$ and $1073 \mathrm{~K}$ using air as gasifying agent (data from CFD simulation result) 


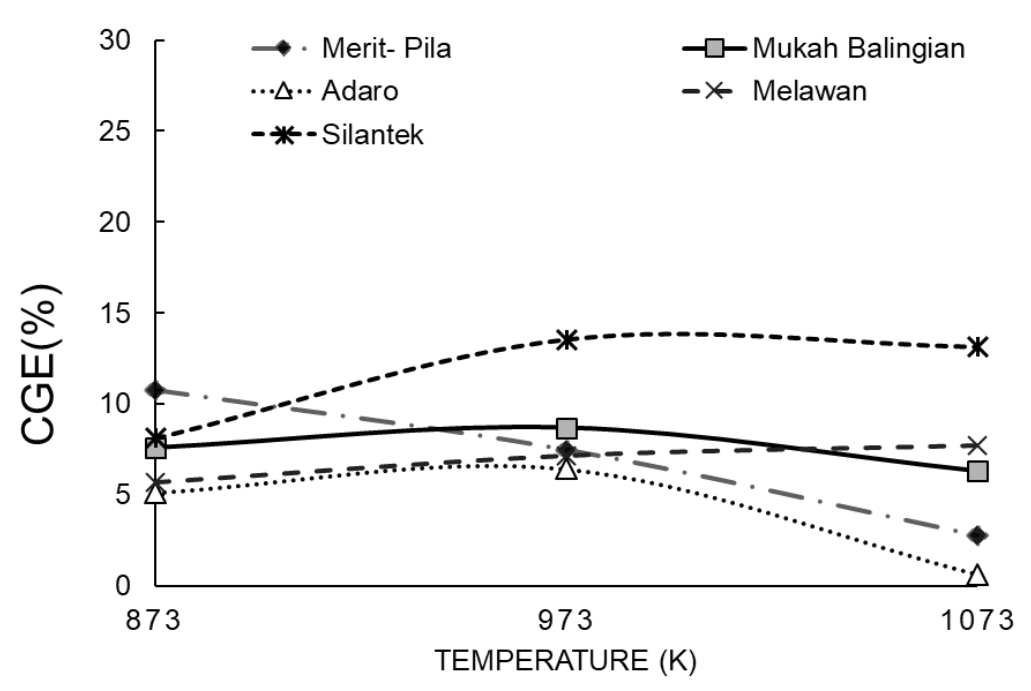

Fig. 4. CGE of various coals at $873 \mathrm{~K}, 973 \mathrm{~K}$ and $1073 \mathrm{~K}$ using air as gasifying agent (data from CFD simulation result)

\subsection{Comparison between Oxygen and Air gasification}

Figure 5 shows the syngas composition inside gasifier when using oxygen and air as gasifying agents. Overall results show an increase in $\mathrm{CO}+\mathrm{H}_{2}$ value compared to using air as gasifying agents. The high level of $\mathrm{O}_{2}$ enhances the reaction of char with $\mathrm{O}_{2}$ and promotes reactions producing $\mathrm{CO}$ and suppresses the reaction of char with $\mathrm{H}_{2} \mathrm{O}$ as $\mathrm{N}_{2}$ is replaced by $\mathrm{O}_{2}$ [70]. $\mathrm{HRC}$ did not show a significant increase compared to LRC when using oxygen as gasifying agents in terms of combustible syngas $\left(\mathrm{CO}+\mathrm{H}_{2}\right)$ produced at all temperature tested.

However, LHV and CGE results indicated that all LHV and CGE values for all coals tested using oxygen as gasifying agents increase at a lower temperature, $873 \mathrm{~K}$ when compared with $973 \mathrm{~K}$. Further increase in temperature shows a detrimental effect where the values of LHV and CGE decrease. These results differ from HRC gasification where the highest value of LHV was obtained when gasification was conducted at $973 \mathrm{~K}$ for Silantek $(0.19 \%$ increase) coals. The same phenomenon can be seen from the CGE efficiency result.

Thus, it can be concluded that gasification using oxygen will produce higher syngas, LHV and CGE for all type of coals. However, gasification at 873K will increase LRC gasification efficiencies compared to a higher temperature at $973 \mathrm{~K}$ where HRC efficiencies increased. Gasification at $1073 \mathrm{~K}$ shows no beneficial effects for all type of coals when gasified using oxygen as no significant increase of gasification efficiency were detected.

Previous results had shown that using lower operating temperature can increase the LHV and CGE for LRC gasification. Table 8 summarizes the operating temperature and gasifying agent to produce higher CGE for each type of LRC used in this study based on the results in the previous sections. The lower operating temperature of $873 \mathrm{~K}$ with oxygen as gasifying agents is the most suitable condition that can produce the highest gasification efficiencies for all of the LRC used. These results further emphasize that LRC FBG gasification does not require a higher temperature to achieve maximum gasification efficiencies. 


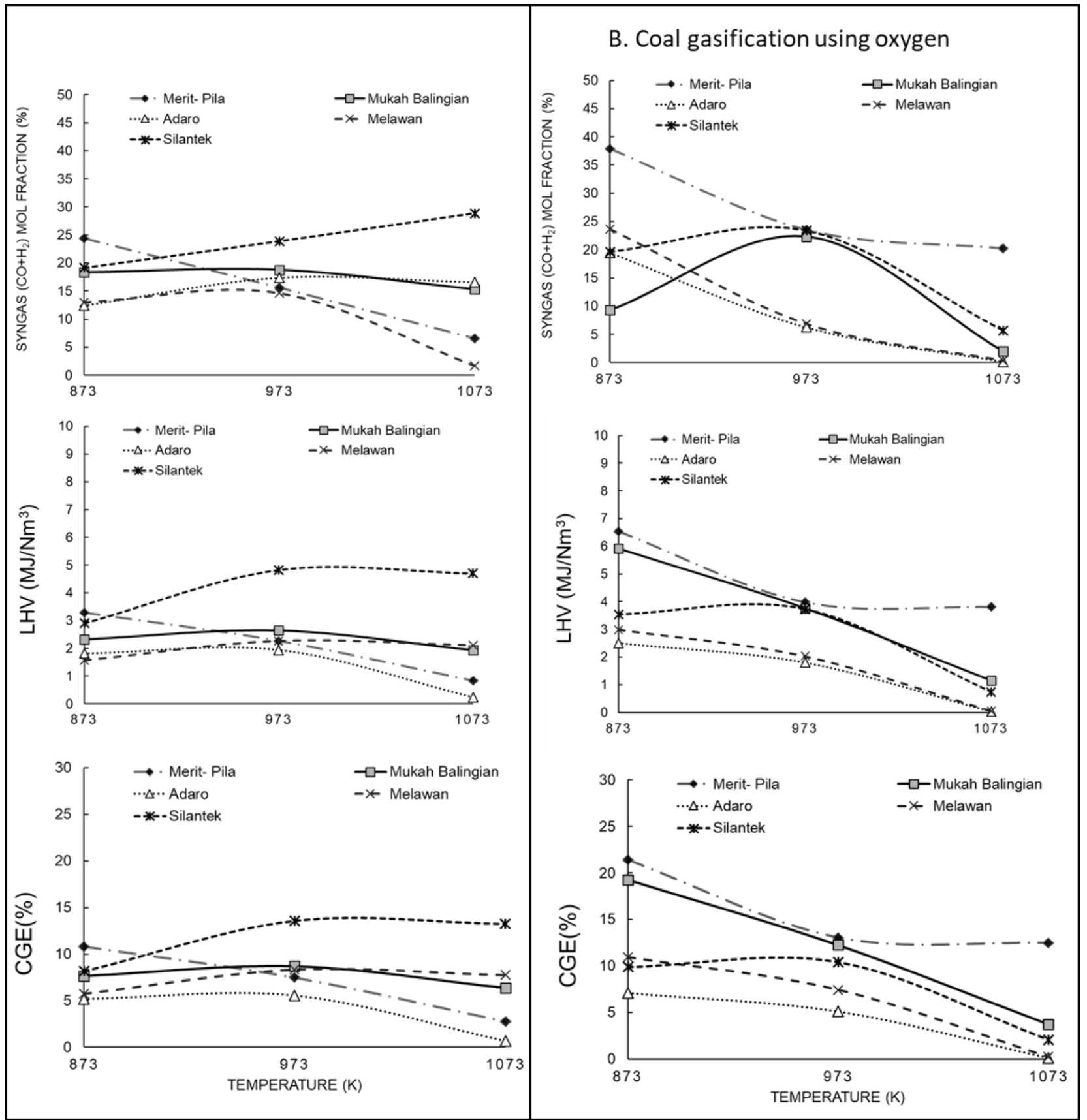

Fig. 5. $\mathrm{CO}+\mathrm{H}_{2}$, LHV and CGE of various coals at $873 \mathrm{~K}, 973 \mathrm{~K}$ and $1073 \mathrm{~K}$ using air and oxygen as gasifying agent (data from CFD simulation results)

Table 8

Suggested suitable operating parameters for LRC tested

\begin{tabular}{llll}
\hline Coal Type & Temperature & Gasifying Agent & CGE $(\%)$ \\
\hline Merit-Pila & $873 \mathrm{~K}$ & Oxygen & 21.39 \\
Mukah-Balingian & $873 \mathrm{~K}$ & Oxygen & 19.27 \\
Melawan & $873 \mathrm{~K}$ & Oxygen & 10.94 \\
Adaro & $873 \mathrm{~K}$ & Oxygen & 7.07 \\
\hline
\end{tabular}




\section{Conclusions}

The result supports the hypothesis that LRC will produce lower syngas, LHV and GCE compared to HRC when using normal operating temperature (973K) and air as the gasifying agent. However, even though it is suggested that increased operating temperature will increase gasification efficiency, it is not entirely true when using LRC as our results suggest lower temperature gives better output compared to a higher temperature at 1073K. It is recommended that the analysis of coal properties is used to predict the gasification output and selection of the suitable operating parameters as the results shows that certain LRC such as Merit-Pila favours gasification at $873 \mathrm{~K}$ while other LRC such as Mukah- Balingian, Melawan and Adaro favours gasification at 973K when gasified using air as the gasifying agent.

It is also concluded that oxygen gasification can increase LHV and CGE for all coals regardless of their type. Our results also predicted that even though oxygen can increase the gasification efficiency for both HRC and LRC, LRC shows a more promising increase at lower temperature compared to higher temperature.

\section{Acknowledgement}

The authors of this paper would like to express their sincere gratitude to Universiti Teknologi MARA (UiTM) for the opportunity to trigger this research and Fundamental Research Grant Scheme (FRGS) from the Malaysian Higher Education Department (Grant No FRGS/1/2019/TK07/UITM/03/4) for financial support. This work was also supported by Universiti Teknologi Malaysia (UTM) and TNB Research Malaysia (TNBR).

\section{References}

[1] International Energy Agency. Office of Energy Technology, R\&D., and Group of Eight (Organization). Energy technology perspectives. International Energy Agency, 2006. https://doi.org/10.1787/9789264109834-en

[2] Fujitsuka, Hiroyasu, Ryuichi Ashida, and Kouichi Miura. "Upgrading and dewatering of low rank coals through solvent treatment at around $350 \mathrm{C}$ and low temperature oxygen reactivity of the treated coals." Fuel 114 (2013): 16-20. https://doi.org/10.1016/i.fuel.2012.12.010

[3] Lin, Boqiang, and Muhammad Yousaf Raza. "Coal and economic development in Pakistan: A necessity of energy source." Energy 207 (2020): 118244. https://doi.org/10.1016/i.energy.2020.118244

[4] Karl, Jürgen, and Tobias Pröll. "Steam gasification of biomass in dual fluidized bed gasifiers: A review." Renewable and Sustainable Energy Reviews 98 (2018): 64-78.

https://doi.org/10.2514/6.2015-1229

[5] Torabi, A., Kazemeini, M., and Fattahi, M. Developing a mathematical model for the oxidative dehydrogenation of propane in a fluidized bed reactor. Asia-Pac. J. Chem. Eng., 11(2016): 448-459. https://doi.org/10.1002/apj.1966

[6] Ocampo, A., E. Arenas, F. Chejne, J. Espinel, C. Londono, J. Aguirre, and J. D. Perez. "An experimental study on gasification of Colombian coal in fluidised bed." Fuel 82, no. 2 (2003): 161-164. https://doi.org/10.1016/s0140-6701(03)91798-x

[7] Bai, Yonghui, Peng Lv, Fan Li, Xudong Song, Weiguang Su, and Guangsuo Yu. "Investigation into Ca/Na compounds catalyzed coal pyrolysis and char gasification with steam." Energy Conversion and Management 184 (2019): 172 179. https://doi.org/10.1016/i.enconman.2019.01.063

[8] Xu, Tao, and Sankar Bhattacharya. "Direct and two-step gasification behaviour of Victorian brown coals in an entrained flow reactor." Energy Conversion and Management 195 (2019): 1044-1055. https://doi.org/10.1016/j.enconman.2019.05.092

[9] Yang, Shiliang, Xiaohuan Liu, and Shuai Wang. "CFD simulation of air-blown coal gasification in a fluidized bed reactor with continuous feedstock." Energy Conversion and Management 213 (2020): 112774. 
https://doi.org/10.1016/j.enconman.2020.112774

[10] Suksuwan, Wasu, Makatar Wae-hayee, and Maizirwan Mel. "The Effect of Single and Double Air Inlets on Swirling Flow in a Reactor of a Fluidized Bed Gasifier." Journal of Advanced Research in Fluid Mechanics and Thermal Sciences 44, no. 1 (2018): 157-166.

[11] Guo, Xuewen, Haixia Zhang, and Zhiping Zhu. "The effect of O2/C ratio on gasification performance and sodium transformation of Zhundong coal." Fuel Processing Technology 193 (2019): 31-38. https://doi.org/10.1016/i.fuproc.2019.04.015

[12] Hayashi, Jun-ichiro, Shinji Kudo, Hyun-Seok Kim, Koyo Norinaga, Koichi Matsuoka, and Sou Hosokai. "Lowtemperature gasification of biomass and lignite: Consideration of key thermochemical phenomena, rearrangement of reactions, and reactor configuration." Energy \& fuels 28, no. 1 (2014): 4-21.

https://doi.org/10.1021/ef401617k

[13] Li, Cheng-Yi, Li-Xin Zhang, Shinji Kudo, Jun-ichiro Hayashi, and Koyo Norinaga. "Toward Low-Temperature Coal Gasification: Experimental and Numerical Studies of Thermochemical Coal Conversion Considering the Interactions between Volatiles and Char Particles." KONA Powder and Particle Journal (2017): 2017008.

https://doi.org/10.14356/kona.2017008

[14] Wang, Ting, and Gary J. Stiegel, eds. Integrated gasification combined cycle (IGCC) technologies. Woodhead Publishing, 2016.

https://doi.org/10.1016/c2014-0-00849-0

[15] Arthur, Christopher J., Muhammad Tajammal Munir, Brent R. Young, and Wei Yu. "Process simulation of the transport gasifier." Fuel 115 (2014): 479-489. https://doi.org/10.1016/i.fuel.2013.07.068

[16] Furusawa, Yusuke, Haruka Taguchi, Siti Norazian Ismail, Sivasakthivel Thangavel, Koichi Matsuoka, and Chihiro Fushimi. "Estimation of cold gas efficiency and reactor size of low-temperature gasifier for advanced-integrated coal gasification combined cycle systems." Fuel Processing Technology 193 (2019): 304-316.

https://doi.org/10.1016/i.fuproc.2019.05.023

[17] Kandiyoti, Rafael, Alan Herod, Keith D. Bartle, and Trevor J. Morgan. Solid fuels and heavy hydrocarbon liquids: thermal characterization and analysis. Elsevier, 2016. https://doi.org/10.1016/B978-008044486-4/50004-0

[18] Lee, See Hoon, Jae Goo Lee, Jae Ho Kim, and Young Chan Choi. "Hydrogasification characteristics of bituminous coals in an entrained-flow hydrogasifier." Fuel 85, no. 5-6 (2006): 803-806.

https://doi.org/10.1016/j.fuel.2005.08.039

[19] Taba, Leila Emami, Muhammad Faisal Irfan, Wan Ashri Mohd Wan Daud, and Mohammed Harun Chakrabarti. "The effect of temperature on various parameters in coal, biomass and CO-gasification: a review." Renewable and Sustainable Energy Reviews 16, no. 8 (2012): 5584-5596.

https://doi.org/10.1016/i.rser.2012.06.015

[20] Meng, Xiangmei, Wiebren De Jong, Ningjie Fu, and Adrian HM Verkooijen. "Biomass gasification in a $100 \mathrm{kWth}$ steam-oxygen blown circulating fluidized bed gasifier: Effects of operational conditions on product gas distribution and tar formation." Biomass and Bioenergy 35, no. 7 (2011): 2910-2924.

https://doi.org/10.1016/j.biombioe.2011.03.028

[21] Żogała, Alina. "Equilibrium simulations of coal gasification-factors affecting syngas composition." Journal of Sustainable Mining 13, no. 2 (2014): 30-38.

https://doi.org/10.7424/jsm140205

[22] Wang, Zhi-Hua, Kang Zhang, Yan Li, Yong He, Min Kuang, Qian Li, and Ke-Fa Cen. "Gasification characteristics of different rank coals at $\mathrm{H} 2 \mathrm{O}$ and $\mathrm{CO} 2$ atmospheres." Journal of Analytical and Applied Pyrolysis 122 (2016): 76-83. https://doi.org/10.1016/i.jaap.2016.10.019

[23] Das, Hirakh Jyoti, Pinakeswar Mahanta, and Rituraj Saikia. "A Future Trend on Research Scope of Numerical Simulation on Conical Fluidized Bed." In Handbook of Research on Developments and Trends in Industrial and Materials Engineering, pp. 401-437. IGI Global, 2020.

https://doi.org/10.4018/978-1-7998-1831-1.ch017

[24] Ismail, Tamer M., and M. Abd El-Salam. "Parametric studies on biomass gasification process on updraft gasifier high temperature air gasification." Applied Thermal Engineering 112 (2017): 1460-1473.

https://doi.org/10.1016/j.applthermaleng.2016.10.026

[25] Sharma, Vikrant, and Vijay K. Agarwal. "NUMERICAL SIMULATION OF COAL GASIFICATION IN A CIRCULATING FLUIDIZED BED GASIFIER." Brazilian Journal of Chemical Engineering 36, no. 3 (2019): 1289-1301. https://doi.org/10.1590/0104-6632.20190363s20180423

[26] Singh, Ravi Inder, Anders Brink, and Mikko Hupa. "CFD modeling to study fluidized bed combustion and gasification." Applied Thermal Engineering 52, no. 2 (2013): 585-614. 
https://doi.org/10.1016/j.applthermaleng.2012.12.017

[27] Kumar, Mayank, and Ahmed F. Ghoniem. "Application of a validated gasification model to determine the impact of coal particle grinding size on carbon conversion." Fuel 108 (2013): 565-577.

https://doi.org/10.1016/i.fuel.2013.02.009

[28] Jeong, Hyo Jae, In Sik Hwang, Sang Shin Park, and Jungho Hwang. "Investigation on co-gasification of coal and biomass in Shell gasifier by using a validated gasification model." Fuel 196 (2017): 371-377. https://doi.org/10.1016/i.fuel.2017.01.103

[29] Fernando, Rohan. "Developments in modelling and simulation of coal gasification." CCC/232 ISBN (2014): 978-92.

[30] Ji, Jieqiang, Leming Cheng, Li Nie, Liyao Li, and Yangjun Wei. "Sodium transformation simulation with a 2-D CFD model during circulating fluidized bed combustion." Fuel 267 (2020): 117175.

https://doi.org/10.1016/i.fuel.2020.117175

[31] Tillman, David A. Coal-Fired Electricity and Emissions Control: Efficiency and Effectiveness. Butterworth-Heinemann, 2018. https://doi.org/10.1016/B978-0-12-809245-3.01001-6

[32] Standard, A. S. T. M. "Standard test method for gross calorific value ofcoal and coke by the isoperibol bomb calorimeter." (1996).

[33] Standard, A. S. T. M. "Standard Test Methods for Proximate Analysis of the Analysis Sample of Coal and Coke by Instrumental Procedures." (1998).

[34] Muda, N., and M. H. Boosroh. "Gasification of coal-petcoke blends in a pilot scale gasification plant." International Journal of Automotive and Mechanical Engineering 8 (2013): 1457. https://doi.org/10.15282/ijame.8.2013.32.0120

[35] Othman, Nor Fadzilah, Mohd Hariffin Bosrooh, and Kamsani Abdul Majid. "Partial gasification of different types of coals in a fluidised bed gasifier." Jurnal Mekanikal 23, no. 1 (2007).

[36] Othman, Nor Fadzilah, Mohd Hariffin Bosrooh, and Kamsani Abdul Majid. "Utilisation Of Malaysian Coal: Merit Pila In The Gasification System." In AIP Conference Proceedings, vol. 1337, no. 1, pp. 33-39. American Institute of Physics, 2011. https://doi.org/10.1063/1.3592439

[37] Basu, Prabir. Combustion and gasification in fluidized beds. CRC press, 2006. https://doi.org/10.1201/9781420005158

[38] Isa, Kamariah Md, Kahar Osman, Nik Rosli Abdullah, Nor Fadzilah Othman, and Mohd Norhakem Hamid. "Gasifying agents type at lower temperature effect on bubbling fluidised bed gasification for low rank coal." Progress in Computational Fluid Dynamics, an International Journal 19, no. 1 (2019): 44-54. https://doi.org/10.1504/pcfd.2019.097598

[39] Che, Yu, Zhou Tian, Zhen Liu, Rui Zhang, Yuxin Gao, Enguang Zou, Sihan Wang, and Boping Liu. "CFD prediction of scale-up effect on the hydrodynamic behaviors of a pilot-plant fluidized bed reactor and preliminary exploration of its application for non-pelletizing polyethylene process." Powder Technology 278 (2015): 94-110. https://doi.org/10.1016/j.powtec.2015.02.022

[40] Cubero, Ana, Alberto Sánchez-Insa, and Norberto Fueyo. "The effect of particle polydispersion in a gasifier bed dynamics using Eulerian-Eulerian models." Fuel Processing Technology 198 (2020): 106216. https://doi.org/10.1016/i.fuproc.2019.106216

[41] Kharoua, Nabil, Lyes Khezzar, and Zoubir Nemouchi. "Study of the pressure drop and flow field in standard gas cyclone models using the granular model." International Journal of Chemical Engineering 2011 (2011). https://doi.org/10.1155/2011/791218

[42] Park, Sang Shin, Hyo Jae Jeong, and Jungho Hwang. "3-D CFD modeling for parametric study in a 300-MWe onestage oxygen-blown entrained-bed coal gasifier." Energies 8, no. 5 (2015): 4216-4236.

https://doi.org/10.3390/en8054216

[43] Klimanek, Adam, Wojciech Adamczyk, Anna Katelbach-Woźniak, Gabriel Węcel, and Andrzej Szlęk. "Towards a hybrid Eulerian-Lagrangian CFD modeling of coal gasification in a circulating fluidized bed reactor." Fuel 152 (2015): 131-137. https://doi.org/10.1016/i.fuel.2014.10.058

[44] Agyemang, Samuel Asomaning. "Computational Fluid Dynamics Modeling of Biomass Gasification in a Fluidized Bed Reactor." PhD diss., North Carolina Agricultural and Technical State University, 2015.

[45] Fluent, A. N. S. Y. S. "14.0 User's Manual." ANSYS Inc., Canonsburg, PA (2011).

[46] Zhu, Lin, Zheng Zhang, Junming Fan, and Peng Jiang. "Polygeneration of hydrogen and power based on coal gasification integrated with a dual chemical looping process: Thermodynamic investigation." Computers \& Chemical Engineering 84 (2016): 302-312.

https://doi.org/10.1016/i.compchemeng.2015.09.010 
[47] Khan, Jobaidur, and Ting Wang. "Implementation of a demoisturization and devolatilization model in multi-phase simulation of a hybrid entrained-flow and fluidized bed mild gasifier." International Journal of Clean Coal and Energy 2, no. 3 (2013): 35-53.

DOI:10.4236/ijcce.2013.23005

[48] Lu, Xijia, and Ting Wang. "Investigation of low rank coal gasification in a two-stage downdraft entrained-flow gasifier." International Journal of Clean Coal and Energy 2014 (2014). DOI:10.4236/ijcce.2014.31001

[49] Jeong, Hyo Jae, Dong Kyun Seo, and Jungho Hwang. "CFD modeling for coal size effect on coal gasification in a twostage commercial entrained-bed gasifier with an improved char gasification model." Applied energy 123 (2014): 29 36.

https://doi.org/10.1016/i.apenergy.2014.02.026

[50] Jones, W. P., and R. P. Lindstedt. "Global reaction schemes for hydrocarbon combustion." Combustion and flame 73, no. 3 (1988): 233-249. https://doi.org/10.1016/0010-2180(88)90021-1

[51] Chen, Chih-Jung, Chen-I. Hung, and Wei-Hsin Chen. "Numerical investigation on performance of coal gasification under various injection patterns in an entrained flow gasifier." Applied energy 100 (2012): 218-228. https://doi.org/10.1016/i.apenergy.2012.05.013

[52] Ghezelchi, Mansoor Hassani, and Hongwei Wu. "Modelling of bio-oil steam gasification in a fluidized bed reactor." Fuel 220 (2018): 575-585. https://doi.org/10.1016/i.fuel.2018.02.036

[53] Askaripour, Hossein. "CFD modeling of gasification process in tapered fluidized bed gasifier." Energy 191 (2020): 116515. https://doi.org/10.1016/i.energy.2019.116515

[54] Zhou, Tao, Shiliang Yang, Yonggang Wei, Jianhang Hu, and Hua Wang. "Impact of wide particle size distribution on the gasification performance of biomass in a bubbling fluidized bed gasifier." Renewable Energy 148 (2020): $534-$ 547. https://doi.org/10.1016/i.renene.2019.10.059

[55] Kumar, Akhilesh, and Ravindra Randa. "Experimental analysis of a producer gas generated by a chir pine needle (leaf) in a downdraft biomass gasifier." International journal of engineering research and applications 4, no. 10 (2014).

[56] Fareeza, N., E. S. Tan, P. Kumaran, T. M. Indra, N. Fadzilah, and K. Yoshikawa. "Evaluating the Effect of Syngas Composition on Micro gas turbine Performance." In Evaluating the Effect of Syngas Composition on Micro gas turbine Performance. IOP Conference Series: Earth and Environmental Science, 32 (1),[012042]. 2016. https://doi.org/10.1088/1755-1315/32/1/012042

[57] Battaglia, Francine, Foster Agblevor, Michael Klein, and Reza Sheikhi. Advancing Coal Catalytic Gasification to Promote Optimum Syngas Production. No. DOE-VT-FE-0024013. Virginia Polytechnic Inst. and State Univ.(Virginia Tech), Blacksburg, VA (United States), 2017. https://doi.org/10.2172/1444101

[58] Ding, Guangchao, and Boshu He. "Process Simulation of Co-Gasification of Raw Municipal Solid Waste and Bituminous Coal in $\mathrm{CO}_{2} / \mathrm{O}_{2}$ Atmosphere." Applied Sciences 10, no. 6 (2020): 1921. https://doi.org/10.3390/app10061921

[59] Dwivedi, Krishna Kant, P. K. Chatterjee, M. K. Karmakar, and A. K. Pramanick. "Pyrolysis characteristics and kinetics of Indian low rank coal using thermogravimetric analysis." International Journal of Coal Science \& Technology 6, no. 1 (2019): 102-112. https://doi.org/10.1007/s40789-019-0236-7

[60] Beamish, B. Basil, Karen J. Shaw, K. A. Rodgers, and Jane Newman. "Thermogravimetric determination of the carbon dioxide reactivity of char from some New Zealand coals and its association with the inorganic geochemistry of the parent coal." Fuel processing technology 53, no. 3 (1998): 243-253.

https://doi.org/10.1016/s0378-3820(97)00073-8

[61] Gomez, Arturo, and Nader Mahinpey. "A new model to estimate CO2 coal gasification kinetics based only on parent coal characterization properties." Applied Energy 137 (2015): 126-133. https://doi.org/10.1016/j.apenergy.2014.10.010

[62] Gonzalo-Tirado, Cristina, Santiago Jimenez, and Javier Ballester. "Kinetics of CO2 gasification for coals of different ranks under oxy-combustion conditions." Combustion and Flame 160, no. 2 (2013): 411-416. https://doi.org/10.1016/i.combustflame.2012.10.020 
[63] Lahijani, Pooya, Zainal Alimuddin Zainal, Abdul Rahman Mohamed, and Maedeh Mohammadi. "CO2 gasification reactivity of biomass char: catalytic influence of alkali, alkaline earth and transition metal salts." Bioresource technology 144 (2013): 288-295.

https://doi.org/10.1016/i.biortech.2013.06.059

[64] Sharma, Atul, Toshimasa Takanohashi, Kayoko Morishita, Takayuki Takarada, and Ikuo Saito. "Low temperature catalytic steam gasification of HyperCoal to produce H2 and synthesis gas." Fuel 87, no. 4-5 (2008): 491-497. https://doi.org/10.1016/i.fuel.2007.04.015

[65] Coetzee, Sansha, Hein WJP Neomagus, John R. Bunt, and Raymond C. Everson. "Improved reactivity of large coal particles by $\mathrm{K}_{2} \mathrm{CO}_{3}$ addition during steam gasification." Fuel processing technology 114 (2013): 75-80. https://doi.org/10.1016/i.fuproc.2013.03.041

[66] Dingier, Janet E., Satish Nirula, and Walter Sedriks. "Costs of synthesis gases and methanol." Part II, SRI PEP Report, SRI International, Menlo Park, CA (February 1983) (1983): 17.

[67] Zaccariello, Lucio, and Maria Laura Mastellone. "Fluidized-bed gasification of plastic waste, wood, and their blends with coal." Energies 8, no. 8 (2015): 8052-8068.

https://doi.org/10.3390/en8088052

[68] Majoumerd, Mohammad Mansouri, Han Raas, Sudipta De, and Mohsen Assadi. "Estimation of performance variation of future generation IGCC with coal quality and gasification process-Simulation results of EU $\mathrm{H}_{2}$-IGCC project." Applied energy 113 (2014): 452-462. https://doi.org/10.1016/i.apenergy.2013.07.051

[69] Żogała, Alina. "Equilibrium simulations of coal gasification-factors affecting syngas composition." Journal of Sustainable Mining 13, no. 2 (2014): 30-38. https://doi.org/10.7424/jsm140205

[70] Zhang, Zewu, Bowen Lu, Liqi Zhang, Xiaoshan Li, Cong Luo, Yongqing Xu, Zhenghong Zhao, and Chuguang Zheng. "Computational study on the effect of gasification reaction on pulverized coal MILD combustion diluted by N2 and $\mathrm{CO}_{2}$." Applied Thermal Engineering 158 (2019): 113806.

https://doi.org/10.1016/i.applthermaleng.2019.113806 